\title{
On the Nonlinear Relationship between Bank Financing and Firm Performance: A PSTR Model for Tunisian Companies
}

\author{
Abdelaziz Hakimi \\ Dept. of Management, University of Jendouba \\ Faculty of Law, Economics and Management of Jendouba, Tunisia \\ Tel: 216-9708-9263Ｅ-mail: abdelazizhakimi@yahoo.fr
}

Received: December 21, 2017 Accepted: December 25, 2017 Published: December 26, 2017

doi:10.5296/ijafr.v7i2.12348 URL: https://doi.org/10.5296/ijafr.v7i2.12348

\begin{abstract}
Despite that bank lending and firm performance relationship has been strongly explored, to date there are few studies that investigated the threshold of credit that affects firm performance. The aim of this paper is twofold. First, it seeks the optimal threshold of short-term and long-term credits that affects firm performance. Second, it investigates the impact of bank credit of firm performance. To achieve these goals, we used a sample of 36 Tunisian listed companies over the period 2008-2015 and we performed the Panel Smooth Transition Regression (PSTR) as econometric approach. Empirical results indicate that Tunisian firms require more short-term credits than long-term loans based on the optimal threshold. With regard to the impact of bank credit, findings indicate that this effect differs from short-term to long-term credit. We found that firm performance was significantly and positively correlated with short-term credit. However, long-term credit decreases significantly the performance of Tunisian companies. For macroeconomic factors, results show that GDPG increases significantly firm performance; however inflation acts negatively and significantly.
\end{abstract}

Keywords: Bank financing, Firm performance, PSTR model, Tunisian companies

JEL codes: G21, G32, D25 


\section{Introduction}

Several studies highlight the importance of large companies and small and medium-sized enterprises (SME) in the production apparatus (Bagehot 1873, Schumpeter 1911). In the modern economies, SME are considered as the first creators of employment and added value. They contribute in a very significant way to the economic growth and to the nation's wealth. However, the environment in which operate is often confronted to several economic, environmental or political instability. Also, companies are often facing to financial problems like the instability of self-financing, the importance of working capital requirement, inadequacy of stockholders' equity with regard to the capital, the dominance of short-term bank lending in their debts. To minimize the social costs of these money troubles, banks play a leading role for the rescuing and assisting distress firms via the bank credit. Since a few years, most of SME had resorted to bank credits often short-term as source of funding.

Business financing has strongly evolved during these last years. Important modifications have been registered such as the emergence of new financial instruments, the transition from a situation of financial repression to another more liberalized, the switching from an indebtedness economy to market economy. In spite of these changes, the traditional and the classic sources of funding are always the most used.

The relationship between banking financing and firm performance has been investigated in several empirical studies. However, results of these works are inconclusive. There are some studies that supported the positive association, while others defend the perfectly the opposite view. Recently, Fowowe (2017) conducts an empirical investigation of the effects of access to finance on the growth of firms in African countries. He used data for 10,888 firms across 30 African countries. Empirical results indicate that the access to finance constraint exerts a significant negative effect on firm growth. In contrary, Delis et al. (2016) investigated the effect of market power on firm performance. They used a 25,236 syndicated loan facilities granted between 2000 and 2010 by 296 banks to 9,029 US non-financial firms. Empirical findings indicate that bank market power can facilitate access to credit by poorly performing firms. Also, it boosts the performance of the firms that obtain credit.

Banking-firm relationship literature widely documented that banks serve as a source of external finance for businesses, especially for SME and distress companies (Bernanke, 1983; Bernanke and Blinder, 1992, Boot (2000), Boot et al. (1991), Degryse and Van Cayseele (2000), Gobbi and Sette (2011)). There is strong evidence between changes in the level bank credit and the level of firm performance. As for example, Vovchak (2017) examined the relationship between disruptions in bank credit supply and firm performance. Empirical results confirmed that banking relationships are important for firms. Findings suggest that firms with stronger bank relationship had a lower decline in bank credit during the crisis than those whose banks were mainly financed by noncore sources of funding. The author reported a positive relationship between changes in bank credit and firms' stock returns during the crisis.

Silivestru (2012) conducted an analysis on the association between bank loans and small firm financing in Romania during the period 2007-2011. From this study, it showed that more than 
$80 \%$ of Romanian SMEs financed their activities by resorting to self-financing and bank loans. Despite this strong orientation toward bank lending, bank financing remains problematic. Most banks considered that SME loans are more riskily and more costly. Without strong credit history or in absence of exclusive and strong bank-firm relationships, credit decision remains very difficult. In most cases, it is associated with a rejection. This is explained the high percentage of rejected loan applications in Romania. According to the National Bank of Romania, rejection rate was $16 \%$ in 2009 and $15.3 \%$ in 2011.

Based on a questionnaire to a sample of 1,272 MSMEs in Bulgaria, Georgia, Ukraine, and Russia, and by performing panel data analysis, Jõeveer et al. (2006) investigated the effect of bank loans on micro, small and medium sized enterprises (MSMEs). Empirical results indicate that there a positive and significant association between bank financing and most performance indicators. Findings indicate also that credit banking has a positive effect on fixed assets. This result implies that MSMEs allocate bank loans for investment in fixed capital.

Banking financing are very important especially during the period of crisis. Within this situation, firms need more funds to support the economic instability and the new environment marked by many shocks and several unforeseen behavior. Shivardi et al. (2017) used a data set that covers almost all bank-firm relationships in Italy over the period 2004-2013 to test the effect of credit misallocation during the European financial crisis. Empirical findings indicate that less capitalized banks were less likely to cut credit to non-viable firms. Also, credit misallocation increased the failure rate of healthy firms and reduced the failure rate of non viable firms.

Despite that the impact of bank financing on firm performance was well documented in bank-firm relationships literature (Fowowe (2017), Vovchak (2017), Shivardi et al. (2017), Delis et al. (2016)), to our best knowledge there is no paper that investigates the optimal threshold of bank credit which affects the firm performance. This paper fills the gap in the existing literature. First, when we investigated bank financing and firm performance, it is often oriented to non-listed companies since they are unable to access to financial market. In this study, we are based on listed companies. This is in order to seek if there is a complementary relationship between bank and market financing. The second contribution of this paper is that we search the optimal threshold of bank credit (short-term and long-term) that affects firm performance, contrary to the previous studies which investigated only the direct effect of bank lending on firm performance.

The purpose of this paper is twofold. First, it seeks the optimal threshold of short-term and long-term credits. Second, it investigates the impact of bank credit of firm performance. To achieve these two goals, we used a sample of 36 Tunisian listed companies over the period 2008-2015 and we performed the Panel Smooth Transition Regression (PSTR) as econometric approach.

The remainder of this paper is structured as follows. Section 2 presents the PSTR model and specific tests. In section 3 we introduce data and the methodology used in this paper. Section 4 shows the model estimation and discusses results and section 5 concludes. 


\section{Mll Macrothink}

International Journal of Accounting and Financial Reporting

ISSN 2162-3082 2017, Vol. 7, No. 2

\section{The PSTR Model}

The PSTR model, proposed by González et al. (2005), is an extension of the PTR model of Hansen (1999). It is a fixed effects model with exogenous regressors. The PSTR model is considered a nonlinear homogenous panel model. The theoretical modeling of the PSTR is given by the equation (1):

$$
y_{i, t}=\mu_{i}+\beta_{0}^{\prime} x_{i, t}+\beta_{1}^{\prime} x_{i, t} g\left(q_{i, t}, \gamma, c\right)+\varepsilon_{i, t}
$$

For $i=1, \ldots, N$, and $t=1, \ldots, T$, where $N$ and $T$ denote respectively the cross-section and time dimensions of the panel. $y_{i, t}$ is the dependent variable. $u_{i}$ indicates the vector of the individual fixed effects and $g\left(q_{i, t}, \gamma, c\right) g$ is the function of transition which depends on the transition variable of transition( $\left.q_{i t}\right)$, to the parameter of threshold $(C)$ and to the smooth transition parameter $(\gamma), x_{i, t}=\left(x_{i, t}^{1}, \ldots \ldots \ldots, x_{i, t}^{k}\right)$ is a vector of $k \mathrm{k}$ explanatory variables and where $\varepsilon_{i, t}$ is a random disturbance. $\beta_{0}$ and $\beta_{1}$ indicate respectively the parameter vector of the linear model and the non-linear model. The transition function of the PSTR model $g\left(q_{i, t}, \gamma, c\right) g$ allows the system to transit gradually. To well define this transition function,

González et al. (2005), like Granger and Teräsvirta (1993), Teräsvirta (1994), and Jansen and Teräsvirta (1996) propose the following logistic form of $m$ orders in the equation (2):

$$
g\left(q_{i, t}, \gamma, c\right)=\left[1+\exp \left(-\gamma \prod_{j=1}^{m}\left(q_{i, t}-C_{j}\right)\right]^{-1}\right.
$$

Where $\gamma>0, c_{1}<\ldots<c_{m}$ and $c=\left(c_{1} \ldots \ldots c_{m}\right)$ is a vector of level parameter. $\gamma$ represents the supposed positive smooth parameter. Ibarra and Trupkin (2011) reported that if $\gamma$ is very high the PSTR model is considered as a model with two regimes. Hence, the transition function can be written in the equation (3) as follow:

$$
y_{i, t}=\mu_{i}+\beta_{0}^{\prime} x_{i, t}+\sum_{j=1}^{m} \beta_{j}^{\prime} x_{i, t} g\left(q_{i, t}^{j}, y_{j}, c_{j}\right)+\varepsilon_{i, t}
$$




\section{Macrothink}

\subsection{Specific Tests for the PSTR Model}

Before testing the PSTR model, there are some conditions and assumptions that will be tested. The first test aims to check the linearity or homogeneity of the dependent variable and the threshold variable. The second test is done to identify the number of transition functions.

\subsubsection{The Test of Linearity}

The objective of this empirical study is to confirm that there is a non-linear relationship between bank credit and firm performance. To this end, we conduct a test of linearity against the PSTR model. The null hypothesis is $H_{0}: \beta_{1}=0$ and the alternative is $H_{1}: \beta_{1} \neq 0 H$. However, the test will be nonstandard since, under $H_{0}$ the PSTR model contains unidentified nuisance parameters (Note 1$)$. The transition function $g\left(q_{i, t}, \gamma, c\right)$ will be replaced by its first order Taylor expansion round $\gamma=0$. The null hypothesis of this test becomes, $H_{0}: \gamma=0$. The new function of transition can be written as following in the equation (4):

$$
y_{i, t}=\mu_{i}+\beta_{0}^{*} X_{i, t}+\beta_{1}^{*} X_{i, t} q_{i, t}+\cdots+\beta_{m}^{*} X_{i, t} q_{i, t}^{m}+\varepsilon_{i, t}^{*}
$$

Where the parameter vectors $\beta_{1}^{*}, \ldots \ldots, \beta_{m}^{*}$ are multiples of $\gamma$ and $\varepsilon_{i, t}^{*}=\varepsilon_{i, t}+R_{m} \beta^{*} X_{i, t}$ where $R_{m}$ is the residual of Taylor development. This null hypothesis may be conveniently tested by a Wald and Likelihood ratio tests. If we denote $S S R_{0}$ the panel sum of squared residuals under $H_{0}$ (linear panel model with individual effects) and SSR1the panel sum of squared residuals under $H_{1}$ (PSTR model with two regimes), the Wald LM test can be written in the equation (5) as:

$$
L M_{w}=\frac{T N\left(S C R_{0}-S C R_{1}\right)}{S C R_{0}}
$$

Where; $\mathrm{SCR}_{0}$ and $\mathrm{SCR}_{1}$ denote the residual squared sum of the panel under the null hypothesis (lineair panel model with individual effects) and the residual squared sum of the panel under the alternative hypothesis (PSTR model with $\mathrm{m}$ transition). If the sample size is small, Gonzàlez et al. (2005) suggest the use of the Fisher statistics (LMF) which is defined in the equation (6) as:

$$
L M_{w}=\frac{T N\left(S C R_{0}-S C R_{1}\right) / m k}{S C R_{0} / T N-N-m k}
$$

Where; $k$ is the number of explanatory variables. $L M_{F}$ is assumed to follow Fisher distribution 
with $m k$ and $T N-N$ - $m k$ degrees of freedom $(F(m k, T N-N-m k))$. Under the null hypothesis,

all linearity tests follow a chi-2 distribution with $k$ degrees of freedom $\left(\chi^{2}(k)\right)$.

\subsubsection{Test of Number of Transition}

This test consists to identify the number of the function of transition. This test aims to check the null hypothesis when the PSTR model has one function of transition $(m=1)$ against the alternative hypothesis when the model has at least two functions of transition $(m=2)$. Decisions of this test are based on the $L M_{w}$ and $L M_{F}$ statistics. If the coefficients are statistically significant at level of $5 \%$, we reject the null hypothesis and we admit that it exist at least two functions of transition. Otherwise, we can't reject the null hypothesis and we conclude that the model has one threshold.

\section{Data and Methodology}

To investigate the impact of bank credit on the firm performance we used a sample of 36 Tunisian listed firms over the period 2008-2015. Data are collected from the annual report of each company. In this study, financial institutions are excluded due to their financial structure. It should be mention that in 2015; only 78 firms are listed in the Tunis Stock Exchange. However, we limit our study to the non-financial institutions and it's for this reason that we retain only 36 firms for all the period of study. The number of listed companies crossed from 50 in 2008 to reach 78 firms in 2015. Most of these companies are financial institutions such as banks, insurance and other financial services institutions. The evolution of the number of Tunisian listed companies is presented in the Table 1 below.

Table 1. Number of Tunisian listed firms and market capitalization

\begin{tabular}{lcccccccc}
\hline Years & 2008 & 2009 & 2010 & 2011 & 2012 & 2013 & 2014 & 2015 \\
\hline Number & 50 & 52 & 56 & 57 & 59 & 71 & 77 & 78 \\
\hline Market capitalization in \% of GDP & 17 & 21 & 24.1 & 22.1 & 19.5 & 18.8 & 21.4 & 20.9 \\
\hline
\end{tabular}

Source: Annual report of the Tunis Stock Exchange

The hypothesis that bank credit and firm performance are nonlinear motivates us to apply the PSTR model. Based on the previous studies that investigate this relationship and which are ambiguous, we think that an increase of bank credit may not necessarily be associated with an increase of performance and vice versa. The application of this model depends on whether the two variables are nonlinear or not.

\subsection{The Model and Variables Definition}

To investigate the impact of bank credit on the Tunisian listed firms, we will specify the two following models. In the first one, we search the effect of short-term credit on the firm 
performance. Also, we aim to determine the necessary threshold of credit that can affect bank performance. In the second one, we test the effect of long-term credit on the performance of Tunisian listed companies. Like the first one, the threshold of credit will be investigated in this model.

In the two models, firm performance was explained by the main firm specifics (Size, Age and Leverage), bank credit (short-term and long-term credit) and macroeconomic specifics (annual growth of Gross Domestic Product (GDPG) and inflation rate (INF))

$$
\begin{array}{lr}
\boldsymbol{R O A}_{i, t}=\operatorname{SHORTC}_{i, t}+\operatorname{SIZE}_{i, t}+\operatorname{AGE}_{i, t}+L E V R_{i, t}+G D P G_{t}+I N F_{t}+\varepsilon_{i, t} & \text { Model (1) } \\
\boldsymbol{R O A}_{i, t}=\operatorname{LONGTC}_{i, t}+\operatorname{SIZE}_{i, t}+\text { AGE }_{i, t}+L E V R_{i, t}+G D P G_{t}+I N F_{t}+\varepsilon_{i, t} & \text { Model (2) }
\end{array}
$$

Where;

$(R O A)$ is the return on Assets measured by the net profit divided by the total Assets. There are several financial and non financial measures of performance. As documented in several previous studies (Chong 2008, Santos and Brito, 2012, Fowowe 2017), financial measures can includes, returns on investment (ROI), returns on equity (ROE), return on Assets (ROA), earnings per share (EPS), Tobin's Q ratio . Non-financial measures maybe proxied by number of employees, revenue growth, revenue per employee, market share. However, the non-financial measures have the disadvantage of being subjective (Santos and Brito, 2012; Chong, 2008). It's for this reason that we apply for financial measures but we limited our work only for the returns on Assets (ROA). This choice is justified by the fact that only this measure is nonlinear with the performance of firm. However, the nonlinearity hypothesis was rejected for all other measures.

(SHORTC) is the short-term credit granted to firm and measured by the Napierian logarithm of total short-term credits. (LONGTC) is the long- term credit granted to firm and measured by the Napierian logarithm of total long-term credits. As measures of bank credit financing, these two variables were used in several previous studies (Morgues, 1994; Severin, 2012).

(SIZE) is the firm size measured by the Napierian logarithm of total assets. (AGE) is the firm age measured by the difference between the current year and the date of creation. (LEVRAGE) is the debt ratio measured by total long term debt to total equity. As firm specifics these three variables are considered as key determinants that affect the level of performance (Majumdar, 1997; Papadogonas, 2007; Halil and Hasan, 2012; Akinyomi and Olagunju, 2013; Dogan, 2013)

$(G D P G)$ is the annual growth of Gross Domestic Product. (INF) is the inflation rate measured by the index of customer price. Macroeconomic in which operate companies can affect the level of performance. It's for this reason that we introduce in our econometric model two macroeconomic variables (Oliver; 2000, Chee chee and Herbeman; 2002). 


\section{Empirical Results and Discussion}

In this section, we will present and discuss empirical findings. Before testing the PSTR model and the jointly tests, we will give firstly a descriptive analysis of our data and the correlation matrix. Secondly, the test of stationarity, linearity and the test of the number of transition are performed and discussed. Finally, we estimate the PSTR model.

The Table 2 below summarise descriptive statistics for all variables used in our study. For each variable, we give average value, median, standard deviation, minimum and maximum values. Descriptive statistics are presented to describe the basic characteristics of data used in this study concerning 36 firms over the period from 2008 to 2015.

Table 2. Descriptive statistics

\begin{tabular}{lcccccccc}
\cline { 5 - 8 } & & & & & \multicolumn{3}{c}{ Quantiles } \\
\hline Variables & $\mathrm{N}$ & Mean & S.D. & Min & .25 & Mdn & .75 & Max \\
\hline ROA & 286 & 0.03 & 0.10 & -0.28 & 0.00 & 0.04 & 0.08 & 0.10 \\
LONGC & 278 & 15.18 & 1.86 & 7.24 & 14.47 & 15.62 & 16.39 & 18.50 \\
SHORTC & 275 & 15.15 & 2.14 & 5.15 & 14.37 & 15.65 & 16.43 & 18.91 \\
AGE & 288 & 40.08 & 17.35 & 5.00 & 28.00 & 36.00 & 50.00 & 90.00 \\
SIZE & 288 & 7.75 & 0.41 & 6.48 & 7.52 & 7.73 & 7.98 & 9.68 \\
LEVR & 281 & 0.18 & 0.54 & 0.00 & 0.04 & 0.11 & 0.19 & 7.92 \\
GDPG & 288 & 0.02 & 0.02 & -0.02 & 0.02 & 0.03 & 0.04 & 0.04 \\
INF & 288 & 0.05 & 0.01 & 0.04 & 0.04 & 0.05 & 0.05 & 0.06 \\
\hline
\end{tabular}

The average ROA was $3 \%$ with a maximum value of $10 \%$ and a minimum value of $28 \%$. The number of bank relationships recorded a mean value of 2.8 and 10 relations as a maximum value. The average value of short-term credit is about 15.18 with a minimum of 7.24 and a maximum of 18.50. With regard to the long-term credit, descriptive statistics shows that the average is 15.15 and the maximum and the minimum values are respectively about 18.91 and 5.15. It's forth recalling that these two variables are in Napierian logarithm and to have more precise value we must practice the exponential function to these two variables in order to get the necessary amount of short-term and long-term credit.

For the firm age, the average value is 40.08 with a minimum value around 28 years and a maximum of 90 years. The high average age for Tunisian listed companies indicates that these firms are more experienced and this can improve their productive efficiency over the time. The average size (SIZE) is about 7.75 with a maximum value of 9.68 and a minimum value of 6.48. Like short-term and long-term credit, this variable is in Napierian logarithm and to have more precise value, we should practice the exponential function.

As macroeconomic variables, the GDPG records an average of $2 \%$ with a maximum value of $4 \%$ and a minimum of $-2 \%$. The second variable is the inflation rate. The average of this variable is $5 \%$ and the maximum and the minimum levels are respectively $6 \%$ and $4 \%$. 


\section{MIN Macrothink}

International Journal of Accounting and Financial Reporting

ISSN 2162-3082

2017, Vol. 7, No. 2

After giving some statistics about all variables of our study, the following table gives the level and nature of correlation that exists between variables used in the econometric model. Table 3 below presents the correlation matrix which gives information on the level and the nature of linkages between variables by determining the coefficients of linear correlations of them taken two by two.

Table 3. Correlation Matrix

\begin{tabular}{lllllllll}
\hline & ROA & LONGC & SHORTC & AGE & SIZE & LEVR & GDPG & INF \\
\hline ROA & 1.0000 & & & & & & & \\
LONGC & -0.1662 & 1.0000 & & & & & & \\
SHORTC & -0.2106 & 0.5466 & 1.0000 & & & & & \\
AGE & 0.1868 & 0.0839 & 0.0690 & 1.0000 & & & & \\
SIZE & 0.1125 & 0.2698 & 0.2858 & 0.4158 & 1.0000 & & & \\
LEVR & 0.5051 & 0.2279 & 0.1591 & -0.0763 & -0.2131 & 1.0000 & & \\
GDPG & 0.1077 & -0.0161 & -0.0880 & -0.0458 & -0.0671 & 0.0039 & 1.0000 & \\
INF & 0.0340 & 0.0753 & 0.1129 & 0.0608 & 0.0443 & 0.1252 & 0.4233 & 1.0000 \\
\hline
\end{tabular}

From Table 3, it can be seen that the short-term and the long term credits decrease bank firm performance. However, the rest of variables such as firm age, size, leverage and the two macroeconomic variables are positively associated with the performance of Tunisian firms. The second observation that can be drawn from this table is that there is no high correlation between variables. The only exception is the high level of correlation between short-term and long-term credit (54.66\%). This leads to confirm the absence of the multicollinearity problem.

\subsection{Threshold Specification from Bank Financing to Firm Performance}

Before testing the PSTR model, there are some pre-tests that should be checked. The first one tests for stationarity of all variable used in this study. The second aimed to test the linearity or homogeneity and the third test is done to identify the number of transition function. Table 4 presents results of the panel unit root test. However, Table 5 below summarizes results of the test of linearity based on the statistics of LM Wald, LM Fisher and LR tests.

The procedures of PSTR specification rely on the assumption that all variables in Model (1) and (2) are $I(0)$ process. To test for stationarity, we used the Levin, Lin, and Chu (2002) test and the Phillips and Perron (1988) test. Results displayed in table 4 indicate that the LLC and PP tests reject the null hypothesis at $1 \%$ and $5 \%$ significance level for all variables used in this study. From these results, we can conclude that all data are $I(0)$ process. 


\section{Macrothink \\ International Journal of Accounting and Financial Reporting \\ ISSN 2162-3082 \\ 2017, Vol. 7, No. 2}

Table 4. Panel unit root test (PURT)

\begin{tabular}{lcc}
\hline Variables & Levin, Lin \& Chu t* & PP - Fisher Chi-square \\
\hline ROE & $-9.928^{* * * *}$ & $130.462^{* * *}$ \\
SHORTC & $-20.243^{* * *}$ & $72.6633^{* * *}$ \\
LONGC & $-21.141^{* * *}$ & $163.322^{* * *}$ \\
AGE & $-19.257^{* * *}$ & $124.546^{* * *}$ \\
SIZE & $-5.132^{* * *}$ & $154.271^{* * *}$ \\
LEVR & $-6.695^{* * *}$ & $87.029^{* * *}$ \\
GDPG & $-16.829^{* * *}$ & $260.206^{* * *}$ \\
INF & $-5.863^{* * *}$ & $252.448^{* * *}$ \\
\hline
\end{tabular}

Note: $(* * *),(* *)$ denote significance at $1 \%$ and $5 \%$, respectively.

The Table 5 shows that the null hypothesis is rejected at the $1 \%$ and $5 \%$ levels for the three tests. Also, linearity is rejected for the two models relatives to the effect of short-term and long-term credit on the firm performance. Results imply that there exists non-linear relationship between short-term, long-term credit and Tunisian firm performance. We thus employ the estimation of non-linear model using the PSTR estimation.

Table 5. Linearity test

\begin{tabular}{lcc}
\hline Tests & Short-term credit & Long-term credit \\
\hline Lagrange Multiplier (W) & 11.682 & 8.997 \\
& $(0.008)$ & $(0.041)$ \\
Lagrange Multiplier (F) & 3.395 & 4.327 \\
& $(0.019)$ & $(0.012)$ \\
Likelihood-ratio test (LR) & 11.996 & 9.106 \\
& $(0.007)$ & $(0.046)$ \\
\hline
\end{tabular}

After checking the stationarity and the non-linearity hypothesis between bank credit and firm performance, the second step consists to search the threshold of short-term and long-term credit that affects firm performance. In other words, we will determine the optimal level of credit from which firm performance will be positively or negatively affected. 


\section{Mll Macrothink}

International Journal of Accounting and Financial Reporting

ISSN 2162-3082

Table 6. Threshold values

\begin{tabular}{lcc}
\hline Search for threshold level & Short-term credit & Long-term credit \\
\hline$\gamma$ & 5.000 & 5.000 \\
$\boldsymbol{C}$ & & \\
& $\mathbf{1 6 . 2 5 7}$ & $\mathbf{1 4 . 5 8 0}$ \\
Equivalent amount of credit & 11490142 & 2147897 \\
AIC & -5.966 & -6.074 \\
BIC & -5.814 & -5.909 \\
\hline
\end{tabular}

Table 6 indicates that the threshold of short-term credit is 16.257 and 14.58 for long-term credit. Since these two variables are in logarithm, we should practice the exponential function to the constant $(\mathrm{C})$ to get the optimal level of credit that affects firm performance. Hence, the thresholds of credit are respectively $11490142 \mathrm{MD}$ for short-term credit and $2147897 \mathrm{MD}$ for long-term credit. We notice that the short-term credit is almost 5 times higher that long-term credit. These results indicate that in the short-term, Tunisian listed companies require more funds rather than the long-term. Another argument can be advanced to explain these thresholds. Most Tunisian firms are small medium size enterprises (SME) and theses firms needs more short-term funds than long-term credits.

\subsection{Discussion of Results of the PSTR Model}

Table 7 presents the estimation of PSTR model for the whole sample of 36 Tunisian listed firms during the period 2008-2015. It should be noted that we estimate two models. The first one tests the effect of short-term credit on the firm performance and the second is relative to the impact of long-term credit. The estimation is done by applying nonlinear least squares to data eliminated the individual effects.

Table 7. Coefficient estimation of the PSTR model

\begin{tabular}{lcccc}
\hline & \multicolumn{2}{c}{ ROA (Model 1) } & \multicolumn{2}{c}{ ROA (Model 2) } \\
\hline Variables & Coeff & T-stat & coeff & T-stat \\
\hline PIB & 0.601 & $2.387 * *$ & 0.617 & $2.859^{* * * *}$ \\
INF & -0.969 & -1.337 & -1.552 & $-2.259 * *$ \\
SHORTC & 0.573 & $3.22^{* * *}$ & - & - \\
LONGTC & - & - & -10.811 & $-5.144 * * *$ \\
SIZE & 0.022 & 0.705 & -0.037 & -1.374 \\
LEVR & -0.035 & -0.475 & -0.965 & $-4.447^{* * *}$ \\
AGE & -0.002 & -0.973 & 0.003 & 1.151 \\
SHORTC*TRANSF & 0.524 & $2.850^{* * *}$ & - & - \\
LONGT*TRANSF & - & - & -0.494 & $-2.972 * * *$ \\
SIZE*TRANSF & -0.015 & $-3.462^{* * *}$ & -0.028 & $-6.411^{* * *}$ \\
LEVR*TRANSF & -0.016 & $-2.220^{* *}$ & -0.838 & $-3.857^{* * *}$
\end{tabular}




\begin{tabular}{|c|c|c|c|c|}
\hline AGE*TRANSF & 0.001 & $1.994 * *$ & 0.003 & $5.344 * * *$ \\
\hline$C$ & 16.257 & & 14.580 & \\
\hline$\gamma$ & 5.000 & & 5.000 & \\
\hline Obs & 275 & & 268 & \\
\hline
\end{tabular}

$* * *$ and $* *$ indicate level of significance respectively at $1 \%$ and $5 \%$

Results displayed in Table 7 indicate that short-term and long-term credits affect significantly at $1 \%$ the Tunisian firm performance. We found that short-term credit increases significantly firm performance, however long-term credits act negatively.

For companies, bank credit is a means of funding that support their activities, improve their productivity and stimulate economic growth. The short-term bank credits have for object to insure the balance companies' account. The short-term credit contracted by SME is often granted with lower interest rate compared to those of long-term. These low interest rates lead to a reduction in financing costs and consequently increase firm performance. However, in the short term, company can be exposed to an insufficiency in working capital. Taking into the size of Tunisian companies which are medium and small sized, short term credit is most appropriate for these firms. It's worth recalling that our sample is made by non-financial listed companies. Hence, these firms can be financed in the financial marked and yet, we found that bank credit acts significantly on firm performance. This result confirms a complementary relationship of bank financing and under financial market.

Contrary to the effect of short-term credit, long-term credit acts negatively and significantly at $1 \%$ on the performance of Tunisian listed companies. An increase of long-term credit decreases the performance of Tunisian firms. Although that long-term credits are associated with long-term relationships which can solve the problem of asymmetric information and reduce the credit market imperfection, we found that long-tem credits decrease significantly the firm performance. Generally, long-term loans are contracted with higher interest rates which increase the funding cost. Also, long-term loans require more guarantees, this can limit the companies independence in term of their intangible and tangible assets. These assets are presented as mortgage, which limits their activities and their productivities. Our results are in line with Diamond (1991) which supported the negative impact of long-term credit.

Results indicate that the leverage ratio (LEVR) acts negatively and significantly at $1 \%$ of significance on the firm performance. This means that an increase of total debt compared to total assets decreases significantly the performance of Tunisian companies. Various theories are based on the determinants of capital structure and how this capital structure can affects firm value or performance (Modigliani and Miller (1958), Modigliani and Miller (1963) and Miller (1977). Our results indicate that higher leverage is associated with lower performance. The higher leverage or the high debt (debt overhang) leads to higher agency costs stemming from the conflict between shareholders, managers and bondholders, resulting either in underinvestment or investment in overly risky projects. Our results are in line with Rajan Zingales 1995, Majumdar and Chhibber 1999, Pandey 2002, Ghosh 2008). 
With regard to the macroeconomic variables, results show that GDPG exerts a positive and significant impact on the firm performance; however the effect of inflation is negative. These results indicate that firm performance is conditioned by the macroeconomic environment in which operate.

GDPG acts positively and significantly on the Tunisian firm performance. This result implies that an increase in the level of economic activity is accompanied by increases in ROA. Under a stable macroeconomic environment, firms invest more and improve their activities which lead to an increase in their performance. Also, an increase in economic activity flows through to sales activity and thus positively affects ROA. This result supports findings of McNamara and Duncan (1995).

There is no consensus relative to the effect of inflation on the financial performance or for real activity or real economy. This effect is ambiguous; it may be positive or negative. Hence, it was useful to search for the threshold from which inflation has adverse impact on the firm performance. Our results reveal a negative and significant association between inflation and performance. These results support that higher inflation rates are associated with greater variability of stock return. Also, higher inflation implies less long-run financial activity. Our results corroborate findings of Boyd and Smith (1998), Huybens and Smith (1998, 1999).

Let turn to the effect of our independent variable taking into the transition function. In other words, we will interpret the impact of these variables combined with the optimal threshold of short-term and long-term credits. Results displayed in table 7 show that short-term credit (SHORTC*TRANSF), long-term credits (LONGC*TRANSF) and leverage (LEVR*TRANSF) maintained the same negative and significant effects that have been discussed above. However, the effects of the firm size (SIZE*TRANSF) and the firm age (AGE*TRANSF) become significant.

From a threshold of 16.257 (Note 2) of short-term credit and 14.580 of long -term credit, an increase of firm size decreases significantly the performance of the Tunisian listed companies. The negative relationship has been explained by the structural inertia theory. More than the firm becomes larger, the volume of bureaucracy increases and this may cause stiff resistance to change which will ultimately decrease the level of profit. This result is in line with Hannan and Freeman (1984), Amato and Burson (2007). In contrary, findings indicate that an increase in the firm age (AGE) is associated with an increase of performance. This result means that if firms become older, their performance will be improved. The theory of learning by doing, explains the positive relationship. Our results support the finding of Halil and Hasan (2012); Papadogonas (2007) and different from Pervan et al. (2017) and Lwango et al. (2017)

\section{Conclusions and Policy Implications}

Using a sample of 36 Tunisian listed companies over the period 2008-2015 and performing the Panel Smooth Transition Regression (PSTR) as econometric approach, the aim of this paper was to determine to optimal threshold of bank credit and to test the effect of bank financing of the performance of non-financial Tunisian listed firms. Results of PSTR model indicate that Tunisian firms require more short-term credits than long-term loans based on the 
optimal threshold. This result suggests that Tunisian companies have resort to short-term credit than long-term credit. Considering some firm specifics of Tunisian companies like size, age and financial structure, the short-term credit is seemed to be the most suitable source of funding.

With regard to the impact of bank credit, findings indicate that this effect differs from short-term to long-term credit. We found that firm performance was significantly and positively correlated with short-term credit. However, long-term credit decreases significantly the performance of Tunisian companies. The short-term credit contracted by SME is often granted with lower interest rate compared to those of long-term. These low interest rates lead to a reduction in financing costs and consequently increase firm performance. However, in the short term, company can be exposed to an insufficiency in working capital. Taking into the size of Tunisian companies which are medium and small sized, short term credit is most appropriate for these firms. In contrary, long-term loans are contracted with higher interest rates which increase the funding cost. Also, long-term loans require more guarantees, this can limit the companies independence in term of their intangible and tangible assets. These assets are presented as mortgage, which limits their activities, improve their productivities.

For macroeconomic factors, results show that GDPG increases significantly firm performance; however inflation acts negatively and significantly. Under a stable macroeconomic environment, firms invest more and improve their activities which lead to an increase in their performance. Also, an increase in economic activity flows through to sales activity and thus positively affects ROA.

This paper has some relevant policy implications. First, it determines the optimal threshold of bank credit that affects the firm performance. Policy makers, financial analysts and investors are able to specify the optimal level of bank credit and consequently avoid the debt overhang situation that affects negatively the firm performance and the real economy. Also, results in this paper could be of great interest since it will able for investors in a specific economy to make decision between short-term and long-term financing.

\section{References}

Akinyomi. O., \& A. Olagunju. (2012). Determinants of Capital Structure in Nigeria. International Journal of Innovation and Applied Studies, 3(4), 999-1005.

Amato, L. H., \& T. E. Burson. (2007). The Effects of firm size on profit rates in the financial services. Journal of Economics and Economic Education Research, 8(1), 67-81.

Bagehot, W. (1873). Lombard Street: A Description of the Money Market. New York: Sribner, Armstrong. Edited with an Introduction by P.L. Bernstein, 1999. New York; Chichester: John Wiley and Sons Inc.

Bernake, B.S. (1983). Irreversibility, Uncertainty, and Cyclical Investment. Quarterly Journal of Economic, 98(1), 85-106.

Bernanke, Ben S., \& A. Blinder. (1992). The Federal Funds rate and the channels of monetary policy transmission. American Economic Review, 82, 901-921. 


\section{MInstitute ${ }^{\text {Mink }}$}

International Journal of Accounting and Financial Reporting ISSN 2162-3082 2017, Vol. 7, No. 2

Boot, A.W.A. (2000). Relationship banking: what do we know? Journal of Financial Intermediation, 9, 7-25.

Boot, A.W.A., A.V., Thakor, \& G. F. Udell. (1991). Secured Lending and Default Risk: Equilibrium Analysis, Policy Implications and Empirical Results. Economic Journal, 101, 458-472.

Chee Chee. L., \& S. Haberman. (2002). Macroeconomic Variables and the Demand for Life Insurance in Malaysia. Faculty of Actuarial Science and Statistics, CASS Business School, City University (London).

Chong, H.G. (2008). Measuring performance of small-and-medium sized enterprises: the grounded theory approach. Journal of Business and Public Affairs, 2, 1-10.

Degryse, H., \& P. Van Cayseele. (2000). Relationship lending within a bank-based system: Evidence from European small business data. Journal of Financial Intermediation, 9, 90-109

Delis, M.D., S. Kokas, \& S. Ongena. (2016). Bank Market Power and Firm Performance. Review of Finance, 21(1), 1-28.

Diamond, D. (1991). Monitoring and reputation: the choice between bank loans and directly placed debt. Journal of Political Economy, 99, 689-721.

Dogan, M. (2013). Does firm size affect the firm profitability: Evidence from Turkey data of 200 companies active in the Istanbul Stock Exchange between 2008-2011. Research Journal of Finance and Accounting, 4(4), 53-59.

Fowowe, B. (2017). Access to finance and firm performance: Evidence from African countries. Review of Development Finance, 7, 6-17.

Ghosh, S. (2008). Leverage, foreign borrowing and corporate performance: firm-level evidence for India. Applied Economics Letters, 15(8), 607-616.

Gobbi, G., \& E. Sette. (2011). Do Firms Benefit From Concentrating Their Borrowing? Evidence from the Great Recession. Mimeo, Bank of Italy.

Gonzalez, A., T. Teräsvirta, \& V.D Dick. (2005). Panel smooth transmission regression models. Working Paper Series in Economics and Finance: Stockholm School of Economics.

Granger, C., \& T. Teräsvirta. (1993). Modelling non-linear economic relationships. Oxford University Press.

Halil, E. A., \& A. Hassan. (2012). The effect of firm size on profitability: An empirical Icelandic funds Bitrost. Journal of Social Sciences, 1, 33-42.

Hannan, M.T., \& J. Freeman. (1984). Structural Inertia and Organizational Change. American Sociological Review, 49(2), 149-64.

Hansen, B. E. (1999). Threshold effects in non-dynamic panels: estimation, testing, and inference. Journal of Econometrics, 93(2), 345-368.

Huybens, E., \& B. D. Smith. (1998). Financial market frictions, monetary policy, and capital accumulation in a small open economy. Journal of Economic Theory, 81, 353-400. 


\section{$\triangle$ Macrothink}

International Journal of Accounting and Financial Reporting

ISSN 2162-3082 2017, Vol. 7, No. 2

Huybens, E., \& B. D. Smith. (1999). Inflation, financial markets and long-run real activity. Journal of Monetary Economics, 43, 283-315.

Ibarra, R., \& D. Trupkin. (2011). The relationship between inflation and growth: a panel smooth transition regression approach. Research Network and Research Centers Program of Banco Central (Working Paper).

Jansen, E., \& T. Teräsvirta. (1996). Testing parameter constancy and super exogeneity in econometric equations. Oxford Bulletin of Economics and Statistics, 58(4), 735-763.

Jõeveer, K., F. Pissarides, \& J. Svejnar. (2006). Bank Lending and Performance of Micro, Small and Medium Sized Enterprises (MSMEs): Evidence from Bulgaria, Georgia, Russia and Ukraine. Working paper, Japan Europe Development Fund. Retrieved from https://www.cass.city.ac.uk/_data/assets/pdf_file/0008/78785/Joeveer20Pissarides20Svejnar. pdf

Levin, A., C. F., Lin, \& C. S. J. Chu. (2002). Unit root tests in panel data: Asymptotic and finite-sample properties. Journal of Econometrics, 108, 1-24.

Luukkonen, R., P. Saikokonen, \& T. Terävirta. (1988). Testing linearity against smooth transition autoregressive models. Biometrica, 75, 491-499.

Lwango, A, R. Coeurderoy, A. Gabriel, \& G. Roche. (2017). Family influence and SME performance under conditions of firm size and age. Journal of Small Business and Enterprise Development, 24(3), 629-648.

Majumdar, S. K. (1997). Impact of size and age on firm-level performance: Some evidence from India. Review of Industrial Organisation, 12, 231-241.

Majumdar, S. K., \& P. Chhibber. (1999). Capital structure and performance: Evidence from a transition economy on an aspect of corporate governance. Public Choice, 98, 287-305.

McNamara, R., \& K. Duncan. (1995). Firm Performance and Macroeconomic Variables.

School of Business Discussion Paper No. 66. Retrieved from http//epublications.bond.edu.au/discussion papers/66

Miller, M. H. (1977). Debt and Taxes. Journal of Finance, 32, 261-275.

Modigliani, F., \& M. H. Miller. (1963). Corporate Income Taxes and the Cost of Capital: A Correction. American Economic Review, 53, 433-443.

Modiglinai, F., \& M. H. Miller. (1958). The Cost of Capital, Corporate Finance and the Theory of Investment. American Economics Review, 48, 261-297.

Oliver, B. (2000). Macroeconomics (2nd ed.). Practice Hall New York.

Pandey, I. M. (2002). Capital Structure and Market Power Interaction: Evidence from Malaysia. Discussion paper, Indian Institute of Management Ahmedabad.

Papatogonas, E. M. (2007). Financial performance of large and small firms: Evidence from Greece. International Journal of Financial Service Management, 2(1/2), 14-20.

Pervan, M., I. Pervan, \& M. Ćura. (2017). The Influence of Age on Firm Performance: 


\section{MInstitute ${ }^{\text {Mink }}$}

International Journal of Accounting and Financial Reporting

ISSN 2162-3082

Evidence from the Croatian Food Industry. Journal of Eastern Europe Research in Business and Economics, 1-10.

Phillips, P., \& P. Perron. (1988). Testing for a Unit Root in Time Series Regression. Biometrika, 75(2), 335-346.

Rajan, R., \& L. Zingales. (1995). What Do We Know about Capital Structure? Some Evidence from International Data. Journal of Finance, 50(5), 1421-1460.

Santos, J. B., \& L. A. L. Brito. (2012). Toward a subjective measurement model for firm performance. Brazilian Administration Review, 9, 95-117.

Schivardi, F., E. Sette, \& G. Tabellini. (2017). Credit misallocation during the European financial crisis. EIEF Working Paper 17/04. Retrieved from http://www.eief.it/files/2017/03/wp-174.pdf

Schumpeter, J. (1911). The Theory of Economic Development. Harvard University Press, Cambridge, Ma.

Silivestru, A. R. (2012). Bank loans and small firm financing in Romania. Annales Universitatis Apulensis Series Oeconomica, 14(1), 178-189

Teräsvirta, T. (1994). Specification estimation and evaluation of smooth transition autoregressive models. Journal of the American Statistical Association, 89, 208-218.

Vovchak, T. (2017). Bank Credit, Liquidity Shocks and Firm Performance: Evidence from the Financial Crisis of 2007-2009. Working Paper Series 584, (ISSN 1211-3298). http://dx.doi.org/10.2139/ssrn.2960742

\section{Notes}

Note 1. For more details, see Hansen, (1999) González et al. (2005), following Luukkonen et al. (1998)

Note 2. It is worth recalling that these thresholds are in logarithm, we should practice the exponential function to the constant (C) to get the optimal level of credit that affects firm performance.

\section{Copyright Disclaimer}

Copyright for this article is retained by the author(s), with first publication rights granted to the journal.

This is an open-access article distributed under the terms and conditions of the Creative Commons Attribution license (http://creativecommons.org/licenses/by/4.0/) 